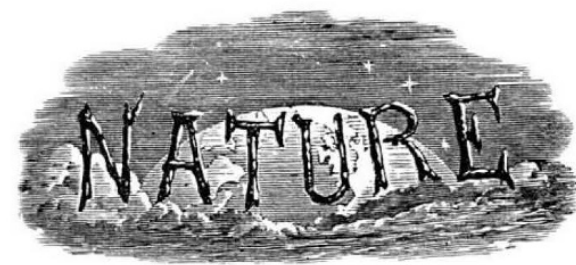

SATURDAY, DECEMBER Io, I932

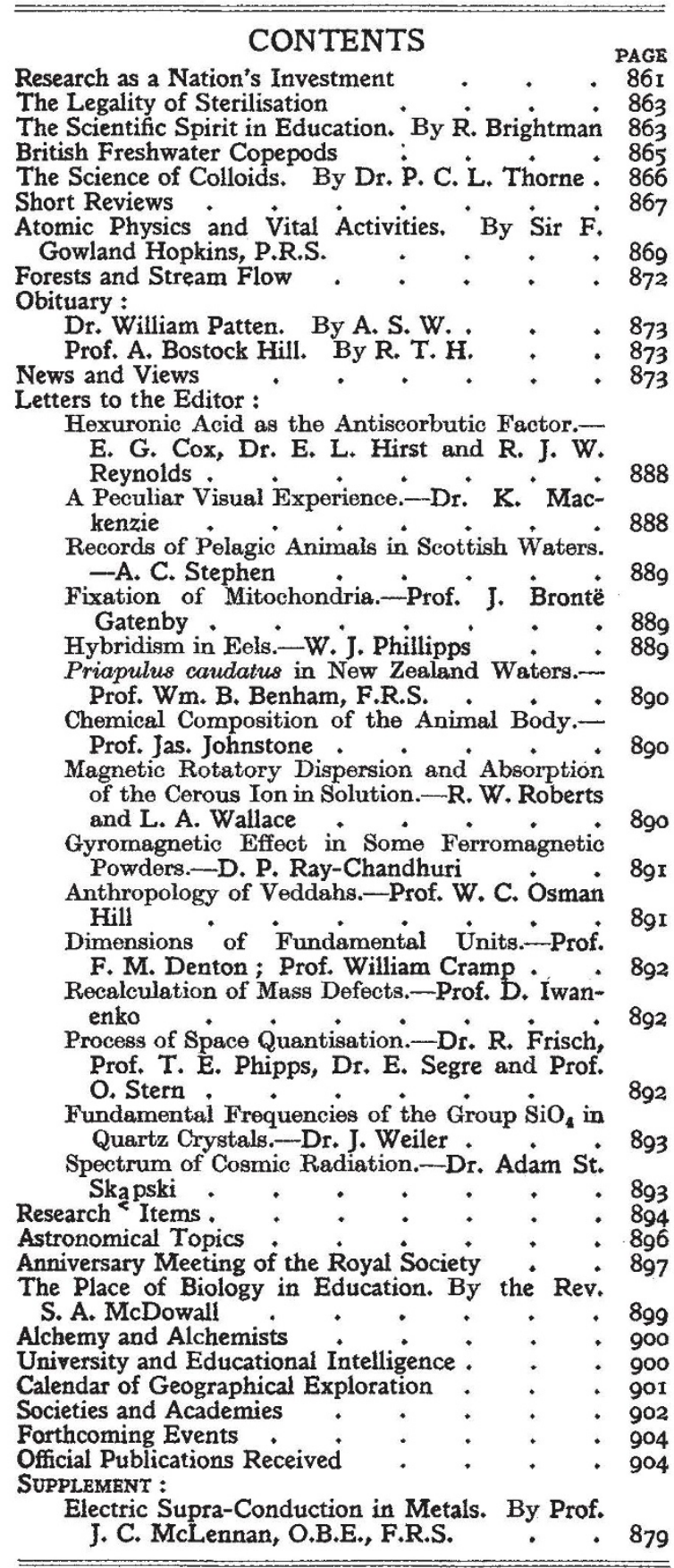

Editorial and Publishing Offices :

MACMILLAN \& CO. LTD.

ST. MARTIN'S STREET, LONDON, W.C.2

No. 3293, VoL. 130]
Research as a Nation's Investment

GOCIAL conventions classify us as workmen, $N$ as employers of labour, as professional persons, as people of leisure, or as the 'idle rich'; but there are times when we all seem to be 'in very much the same boat'. In modern politics a man's vote is worth the same as his master's, and we are getting accustomed to the corollary that this implies an equal degree of responsibility in the public regulation of the affairs of both. One of the more important of these affairs is the means of livelihood, and one of the primary duties of the State is to formulate and carry out such policies as will, in a fundamental and broadly conceived way, promote the material prosperity of its citizens.

If world events during the past fourteen years had not already taught us the lesson, those of the immediate past, and indeed of the present, must surely have made abundantly clear how vitally the ordinary individual in a community such as ours depends for his well-being on the industrial condition of the nation. Business men and operatives may be the first to feel the effects of competition and the loss of markets, but sooner or later the 'sheltered' worker, the professional man, and the gentleman of leisure, whether as earners of income or as payers of tax, are caught in the inevitable undercurrent. The first impulse of each is to exert his bodily strength against the tide, and the second to help another to struggle. No doubt the first few men who fell into the sea struggled likewise, until by research and invention means were found to ride instead of sink; so that to-day the sea is a great highway of commerce, and not merely a human grave. All because man was not content only to turn his face towards 'adverse forces', but went to some trouble, and doubtless to some initial expense, to obtain know. ledge enough to convert a menace into an advantage.

Whether our pre-history is weak or not, this is what passes through the mind on reading Sir Frank Smith's recent Norman Lockyer lecture of the British Science Guild on "Industrial Research and the Nation's Balance Sheet"*, and on looking for some adequate reflection of its thesis in the debate in Parliament on the Address in reply to the King's Speech. The discourse is an opportune contribution to the nation's discussions, and the

* The British Science Guild. The Norman Lockyer Lecture, 1932 : Industrial Research and the Nation's Balance Sheet. By Sir Frank Smith. Pp. 31. (British Science Guild, 6 John Street, London, W.C.2.) 18. 
occasion demands that prominence should be given to hard facts and authoritative opinions concerning the relation which subsists between the organised prosecution of research and the industrial future of Great Britain. In one or other of its aspects the matter has frequently been examined in the columns of NATURE ; nevertheless, so vital is its importance, and so convinced are we that the exigencies of the moment are more likely to obscure than to clarify political vision, that we must return to it again and again without apology, and with all the earnestness at our command.

Four references appear to have been made during the debate following the King's Speech to the part which science must play in solving our industrial problems; we could have wished for a wider appreciation of the real position. Mr. Davies said that the fundamental cause of our depression is the failure to re-adapt our lives to the swift-moving changes brought about by science, which is a partial truth, but not a very helpful pronouncement. The Marquess of Dufferin and Ava expressed the hope that the Government would help in every way scientific research, so that the country might be given a start comparable with that which it had in the nineteenth century; perhaps an assumption that such a policy may be taken for granted may explain the noticeable absence of any echo in the Upper House. The Prime Minister, Mr. Batey, and the noble Marquess referred specifically to the hydrogenation of coal, a process which, if commercially successful, would infuse new life into the coal-mining industry and reduce or arrest the importation of petrol.

Sir Frank Smith's discourse contains statements of fact which show generally, and in this specific instance particularly, how profitable such research is. Five or six years ago, the cost of producing petrol from coal by hydrogenation was estimated to be not less than $2 s$. $6 d$. a gallon, whereas to-day it is $9 d$. ; what it will be five years hence will depend on many factors, not the least of which is the progress of research. The main product is not just some sort of oil, but a No. 1 grade petrol. Now, petrol to the value of $£ 13,690,000$ was imported in 1931, and Sir Frank Smith states that this year the same quantity of petrol may cost us $£ 26,000,000$. In the consideration of figures and opportunities such as these, the cost of the research itself is surely of small moment. Nor are results and prospects far different in other directions of industrial research.
Millions of workers are now employed in the new industries based directly on scientific researchartificial silk, wireless, the generation and use of electric power, motor transport, and the cinema; recent investigations into the storage of applesof which we import nearly eight million pounds worth a year-are believed to have led to an increase in the growers' returns by $£ 100,000$. One reads here of a former loss of $£ 250,000$ in a year which has been reduced to negligible proportions ; there of a loss of fifty million pounds a year which awaits its turn for attention.

Every day in 1931 Great Britain imported on the average more than a million pounds worth of food; how much that we paid for was wasted by deterioration before it could be consumed? If home produce is included, and if (as has been stated) such loss approaches twenty per cent, is not the prize worth an enormously intensified national effort? Research means more than the invention of some ingenious mechanical device which captures the imagination, or alleviates an unwelcome personal exertion; it is not served by romancing Press 'stories' in which a slender basis of fact is made the theme of a sensational announcement. Whether its achievements intrigue the public, or whether they can be appreciated only by technicians, the simple fact is that scientific research has proved itself to be one of the pillars of modern com. petitive industry. What the ordinary citizen so often fails to realise is the part which fundamental scientific research (exemplified by that performed at the universities) and applied technical research (exemplified by that performed by the industries themselves and by such agencies as the Department of Scientific and Industrial Research) is already playing in maintaining him with some degree of stability and comfort in that state of life which he has reached. Nor does he properly appreciate the crash-industrial, political, and social-which would necessarily follow the neglect of opportunities to acquire new knowledge of material resources and new power to use them.

It is the business of scientific men and women to explain to others the position as they know it and the future as they see it. To-day it is more necessary than ever that they should strive to show the voter that research is not merely the concern of the capitalist who uses it to safeguard his possessions; not only the concern of the employer whom it helps to use services and materials to the best advantage; not only the servant of the worker, the conditions of whose

No. 3293, Vol. 130] 
labour have, in many cases, been improved out of all recognition; but also the benefactor of the poor, into whose homes it brings much that was formerly reserved for the rich; and the chief hope of the unemployed, whose chance of a job depends so much on the development of new industries. Where industry and research are concerned, we are indeed all 'in very much the same boat'. The bigger and the better we can make that boat, the happier and the safer we shall be.

\section{The Legality of Sterilisation}

$\mathrm{E}$ ARLY this year a Departmental Committee was appointed by the Minister of Health to examine and report upon the information already available regarding the hereditary transmission and other causes of mental disorder and deficiency, to consider the value of sterilisation as a preventive measure, having regard to its physical, psychological and social aspects, and to the experience of legislation in other countries permitting it, and to suggest what further inquiries might usefully be undertaken in this connexion. This Committee, which is still sitting, is not concerned with the translation into action of any recommendation that it may make, but there is in being a small non-party group, the secretary of which is Wing-Commander A. W. H. James, already prepared with a permissive Bill to legalise the voluntary sterilisation of certain mental defectives, and which has been waiting for the opportunity of introducing this during private members' time. Recently this Parliamentary Sterilisation Committee has circulated to both Houses a memorandum which explains its views and gives a detailed account of the Bill that it is proposed to introduce.

This Bill must surely commend itself to biologists, physicians and lawyers, for it is well drafted, deals only with the mentally deficient (a group with regard to the desirability of whose procreation no doubt has ever been expressed by anyone) and it is a sound project in racial improvement. Many will perhaps deplore the fact that this Bill restricts itself to the mentally deficient, and is meant to apply only to England and Wales. It is greatly to be hoped that it will become law, for the present dubiety concerning the legality of sterilisation cannot possibly be allowed to continue. It would seem that the legality of sterilisation of a normal adult is doubtful. Certainly, a number of sane persons are being sterilised volun- tarily, considering this the most efficient method of contraception, and being convinced that they should not run the risk of producing a second abnormal child; none of these, so far, has been prosecuted. There is little doubt, however, that it is unlawful to sterilise a defective, yet this is being done, but only in the case of the well-to-do. It is because sterilisation might be regarded as being illegal that it remains, for the time being, a luxury for the rich, since State, municipal and charitable institutions dare not do it.

So it is that the well-to-do, through voluntary sterilisation, are preventing the repetition of hereditary blunders, whilst the poor, who outnumber them, cannot imitate them, even though they would. For this reason, if for no others, it is highly desirable that this Bill, a purely permissive Bill, concerned solely with voluntary sterilisation, shall become a law of the land.

\section{The Scientific Spirit in Education}

Education and the Social Order. By Bertrand Russell. Pp. 254. (London: George Allen and Unwin, Ltd., 1932.) $7 s, 6 d$. net.

THIS brilliant and provocative essay on the relation of the individualistic and the civic or social aspects of education is in the true lineage of Thomas Huxley and Prof. H. E. Armstrong and deals out essentially the same trenchant criticism of our crooked thinking and stupid prejudices in this field, above all on the place of science in education that we associate with these pioneers and their followers. Mr. Bertrand Russell's philosophic temper makes the book a contribution to the theory and practice of education which even his opponents ignore at their peril, and his able analysis of the social aspects of the educational problem, no less than his fair but searching criticisms of many of the weaknesses in our present system, should commend the book to all scientific workers who are concerned with the place of science in the modern State.

Like every other thinker of this age, Mr. Russell sees that the future of civilisation depends on co-operation, not merely nationally but also internationally, and he considers that the most vital need of the near future is the cultivation of a vivid sense of citizenship of the world. He recognises that under the transforming hand of science the world has become one economic unit, although the backwardness of our political institutions and 